\title{
LABOR LAW: UNION PREVENTED FROM EXPELLING MEMBERS FOR ENGAGING IN CAMPAIGN TO PASS "RIGHT-TO-WORK" MEASURE
}

A labor union often imposes some form of union discipline over dissident members in order to present a united collective bargaining front. ${ }^{1}$ The recent California case of Mitchell v. International Association of Machinists" illustrates how union discipline may conflict with individual rights of political expression and community interest in free debate.

Mitchell and Mulgrew, long-standing members of the International Association of Machinists, ${ }^{8}$ actively campaigned for a proposed state constitutional amendment which would prohibit both closed and union shops in California. As a result of these activities, they were expelled from the union for conduct "unbecoming a member of the I.A.M." in violation of the Machinist constitution." Thereafter, both Mitchell and Mulgrew filed for a writ of mandate, seeking reinstatement. The trial court held that petitioners had not exhausted their remedies within the union and declined to grant judicial relief.

On appeal, the District Court of Appeal determined that the petitioners were not required to exhaust their internal remedies and there-

${ }^{1}$ The term "union discipline" includes all the punitive measures that can be taken by a union against an offending member. The most common are fines, suspension for a limited period, and expulsion. Expulsion is the most drastic and, consequently, is the primary cause of litigation in this area. See generally Summers, Disciplinary Procedures of Unions, 4 IND. \& LAB. REL. REV. 14 (1951).

${ }^{2}$ 196 Cal. App. 2d 903, 16 Cal. Rptr. 813 (196r), petition for hearing denied, No. 24913 , Cal. Sup. Ct. (1962).

Mitchell, a union member for 17 years, had served in most of the local lodge offices, including that of president. Mulgrew, a member for 6 years, had also served in several official capacities. Opening Brief for Appellants, pp. 2-3.

' INT'L Ass'N Machinists, Const. art. K, $\S_{3}$ (1958). Petitioners did not speak officially for the union, nor did they make representations to that effect. Several decisions have upheld expulsion of a member who claimed to speak officially and misrepresented the union position. See note 14 infra.

$39 \mathrm{CCH}$ Lap. Cas. I 66321 (Cal. Super. Ct. 1960). Under the Machinist Constitution, petitioners had the right of final appeal to the Grand Lodge Convention which was scheduled to convene in September 1960, some fourteen months distant from the date of petitioners' expulsion. The Superior Court held that fourteen months was not an unreasonable delay and consequently, petitioners were premature in seeking judicial relief. By dictum, the court stated that the union action was neither in violation of public policy nor petitioners' constitutional rights. 
fore could properly seek judicial relief. ${ }^{8}$ The court then devoted the greater portion of its opinion to a consideration of the central issue in the case-the right of the union to expel petitioners for engaging in political activity outside the union. ${ }^{7}$ After considering the interests of the union, the petitioners, and the general community, ${ }^{8}$ the appellate court reversed the decision of the lower court, holding that the union had wrongfully expelled petitioners and ordering their reinstatement.

The propriety of union expulsion usually has been determined by contract theory. Under this theory, a union member and the union form a membership contract, the terms thereof being expressed in the union bylaws and constitution. ${ }^{9}$ Expulsion on grounds other than those expressly enumerated gives the expelled union member a cause of action for breach of contract. ${ }^{10}$ As a safeguard against a union's

\footnotetext{
- The appellate court held that fourteen months constituted an unreasonable delay as a matter of law; therefore, petitioners were not required to exhaust their internal union remedies. Many commentators applaud the exhaustion doctrine as a contribution toward internal union democracy, since the members otherwise would have no interest in improving their union's internal adjustment procedure. See Aaron, The LaborManagement Reporting and Disclosure $A C t$ of 1959, 73 HARv. L. REv. 851, 87I (1960); Cox, The Role of Law in Preserwing Union Democracy, 72 HARv. L. REv. 609,615 (1959).

Professor Summers, however, lists five exceptions to the exhaustion doctrine and suggests that "since these are the only grounds on which the courts ever reverse union discipline, the obvious effect of the exception is that if the court will give relief at all, it will do so without requiring any internal appeals." Summers, Legal Limitations on Union Discipline, 64 HARV. L. REv. 1049, 1091 (1951). The truth of this observation is evidenced by the conflict over what constitutes an unreasonable delay. Compare Snay v. Lovely, 276 Mass. 159, I76 N.E. 791 (1931) (over a year's delay not unreasonable), with Van Hook v. Southern California Waiters Alliance, $158 \mathrm{Cal}$. App. 2d 556,323 P.2d 212 (1958) (nine month's delay unreasonable).

7 "The question is whether there will be an excessive loss of freedom if unions are permitted to make political conformity the price of membership." I6 Cal. Rptr. at 819.

${ }^{B}$ The modern union, through its collective bargaining status, exercises vast control over its members' economic lives. Because of this special status, the union assumes reciprocal responsibilities toward its membership and the public generally, and any disciplinary action must be viewed with reference to these other important considerations. Thus, it has been contended that a union must be distinguished from other private organizations, such as fraternal societies and church groups. See Chafee, The Internal Affairs of Associations Not for Profit, 43 HARV. L. REV. 993 (1930).

" "The constitution and by-laws of an unincorporated association express the terms of a contract which define the privileges secured and the duties assumed by those who have become members." Poplin v. Kaplan, 257 N.Y. 277, 278, 177 N.E. 833, 834 (1931). Accord, DeMille v. American Fed'n of Radio Artists, 31 Cal. 2d 139, 187 P.2d 769 (1947), cert. deried, 333 U.S. 876 (1948); Snay v. Lovely, 276 Mass. 159 , 176 N.E. 791 (1931).

${ }^{20}$ See International Ass'n of Machinists v. Gonzales, 356 U.S. 617 (1958) (Court granted reinstatement and damages for lost wages and mental suffering). The Supreme
} 
abuse of its disciplinary powers, courts have required that internal union procedures leading to expulsion conform to a rough standard of due process in accord with the fifth and fourteenth amendments. ${ }^{11}$

Once it has been determined that expulsion was improper, the most prevalent remedy has been reinstatement in the union. ${ }^{12}$ When a union member has sought damages for wrongful expulsion, however, courts have invoked property law principles to determine the measure of damages. Recognizing that union membership is a "property right," on which may depend wages and strike, death, and pension benefits, courts have utilized these property rights as a measure of damages. ${ }^{13}$

While these theories are not a realistic description of the legal relationship existing between a union and its members, but are rather a convenient method upon which to base judicial remedy, they have served the courts reasonably well. When followed with rigid logical con-

Court, in a split decision, held that since an expelled member's cause of action is bared on contract law, state courts are not prevented from granting relief under the doctrine of federal pre-emption.

Some commentators have suggested that a tort action for interference with an advantageous economic relationship would be a more realistic basis for granting relief. See Cox, Law and the National Labor Policy 95-6 (x960); Chafee, supra note 8, at 1007 . This would seem the more appropriate remedy under a closed shop agreement, where expulsion from the union automatically leads to loss of employment. The closed shop agreement, however, is now illegal under the Labor Management Relations Act (Taft-Hartley Act).

${ }^{21}$ As the court said in Coleman v. O'Leary, 58 N.Y.S.2d 812, 815 (Sup. Ct. 1945): "[T] ]echnical precision is not necessary, but the essential fundamentals of fair playnotice and an opportunity to be heard are essential. ..." See Wollett \& Lampman, The Law of Union Factionalism-the Case of the Sailors, 4 Stan. L. REv. 177, 193-4 (1952) and cases cited; Aaron \& Komaroff, Statutory Regulation of Intornal Union Affairs (pts. 1-2), 44 ILl. L. REv. 425, 63x, 66r-2 (1950).

Despite formal safeguards in a minority of union constitutions, providing for a statement of charges, serving of formal notice, formal trial and final appeal to the international convention, serious procedural defects may persist. Professor Williams suggests that the most serious defect is lack of an independent tribunal: "If not manned by union officers, the tribunal is created by them, and the pressures for voting the 'correct' result-that is, the one desired by the officers-is overwhelming." Williams, The Political Liberties of Labor Union Members, 32 TExas L. Rev, 826, 833 (1954).

${ }^{12}$ Although a member's activity was specified as a ground for expulsion, occasionally a court has ordered reinstatement when it felt that the union's action was contrary to public policy. See, e.g., Grand Intl Bhd. of Locomotive Eng'rs v. Green, 280 Ala. 496,98 So. 569 (1923) (declaration of patriotism for country above union loyalty improper ground for expulsion).

${ }^{13}$ See, e.g., Fleming v. Moving Picture Machine Operators, 124 N.J. Eq. 269, I A.2d 386 ( 1938 ) (damages of lost wages). Recoverable damages extend to punitive damages. See, e.g., Grand Int'l Bhd. of Locomotive Eug'rs v. Green, 280 Ala. 496, 98 So. 569 (1923). 
sistency, however, they have led in a few instances to inequitable results. ${ }^{14}$

Commendably, Mitchell abandoned the somewhat mechanical approach of prior cases and made explicit the value judgments on which the decision rested. Taking a pragmatic approach, the District Court of Appeal sought to ascertain the interests of the union, the petitioners, and the community and thereby determine which should be given priority in this instance. Turning first to the legitimate interests of the union, the court recognized that a union could discipline "treasonous" activities by its members. This disciplinary power is necessary to preserve the union's status as an effective collective bargaining agent and may be exercised over members who serve as company spies, ${ }^{15}$ dual unionists, ${ }^{16}$ or impair adherence to the collective bargaining contract. ${ }^{17}$ In "treason" cases, the expelled member is undeserving of judicial sympathy. Moreover, no countervailing interest of the community is impaired, since the union action does not concern the public at large.

Of an entirely different order, according to Mitchell, are those cases in which unions have attempted to discipline members for performing specific citizenship duties. For example, courts have prevented union expulsion of a member for enforcing state laws against a fellow member, ${ }^{18}$ voting in an official capacity for a non-union member to serve on a municipal board, ${ }^{19}$ or testifying against the union before a government commission ${ }^{20}$ or in court. ${ }^{21}$ In this area, the community interest demands that the individual union member fulfill his specific citizenship duty without union interference.

\footnotetext{
${ }^{14}$ Thus, the court in Pfoh v. Whitney, 62 N.E.2d 744 (Ohio App. 1945), accepting the converse of the contract theory, i.e., that any conduct of a member may be punished which is specified in the union constitution, upheld a member's expulsion for distributing Wendell Wilkie circulars without permission of the union president. Summers, supra note 6 , at 1063 , views $P f o h$ as an aberrant result of the contract theory.

${ }^{15}$ Burke v. Monumental Div. 52, Bhd. of Locomotive Eng'rs, 273 Fed. 707 (D. Md. 1919) (reversed on other grounds).

${ }^{10}$ Margolis v. Burke, 53 N.Y.S.2d 157 (Sup. Ct. 1945) (court upheld expulsion of local president for withholding per capita dues and applying to rival union for charter).

${ }^{17}$ United States Rubber Co. \& United Rubber Workers, 21 War. Lab. Rep. I82

(1945) (National War Labor Board upheld union fines assessed members for striking in violation of contract).

${ }^{18}$ Manning v. Klein, I Pa. Super, 2 ro (1895).

${ }^{10}$ Schneider v. Local 60, United Ass'n of Journeymen Plumbers, I16 La. 270, 40 So. 700 (1905).

${ }^{20}$ Abdon v. Wallace, 95 Ind. App. 604, 165 N.E. 68 (1929).

${ }^{21}$ Thompson v. Grand Int'l Bhd, of Locomotive Eng'rs, 4 I Tex. Civ. App. I76, 91 S.W. $834(1905)$.
} 
It seems well established, then, that a union may expel a member who acts in opposition to official union policy in purely economic matters, ${ }^{22}$ but may not expel a member who serves the community under government mandate. The court in Mitchell, however, characterized the advocacy of voluntary unionism as primarily political in nature and falling somewhere between the two extremes. While acknowledging that the International Association of Machinists reasonably might regard voluntary unionism as inimical to its best interests and offcially oppose enactment of "right-to-work" measures, the court denied that the issue was so patently ininical that the union could expel members who took a different stand. ${ }^{23}$ The court dismissed the contention that loss of employment was necessary for judicial intervention. ${ }^{24}$ While petitioners were not deprived of employment, they were deprived of other substantial rights. Because of their expulsion, petitioners were denied any voice in the union, which, as exclusive collective bargaining agent, negotiated the terms and conditions of petitioners' employment. Moreover, although petitioners were not engaged in fulfilling mandatory citizenship obligations, the court regarded the freedom to express political views as so important that it formed "the very heart of a democratic body, pumping the lifeblood of ideas without which our system could

\footnotetext{
${ }^{22}$ In addition to "treasonous" activities there are several other economic misdeeds for which unions validly may expel members. Perhaps the most widely accepted ground is non-payment of union dues. See Summers, Disciplinary Powers of Unions, 3 IND. \& LAB. REL. REv. 483,494 (1950). This ground is codified in $\$ \S 8(\mathrm{a})(3)$ and $8(\mathrm{~b})(2)$ of the Labor Management Relations Act (Taft-Hartley Act) which provide that under a union shop agreement the only ground upon which the union may seek the discharge of a union member is the non-payment of union dues. 61 Stat. 140 (1947), as amended, 29 U.S.C. $\$ \S 158(\mathrm{a})(3),(\mathrm{b})(2)$ (1958). See Note, 45 GEO. L.J. 250 (1957).

${ }^{23}$ In Mitchell, the court reached a question specifically left open in several prior decisions. The California Supreme Court in DeMille v. American Fed'n of Radio Artists, 31 Cal. 2d 139, 187 P.2d 769 (1947), cert. denied, 333 U.S. 876 (1948), held that the union could expel a member who refused to help finance a union campaign to defeat passage of a state right-to-work measure. The United States Supreme Court in International Ass'n of Machinists v. Street, ${ }_{367}$ U.S. 740 (1961), however, narrowly interpreted the Railway Labor Act, 44 Stat. 577 (1926), as amended, 45 U.S.C. $\$ \S 151$ 88 (1958), to prohibit expenditure of members' dues for political purposes. In neither case was the question of required personal indorsement of official union policies considered. As the California court said of DeMille: "[H]e had and continued to have absolute freedom to think or announce what views he pleased. ..." 31 Cal. 2d at 151, 187 P.2d at 777. See Cox, op. cit. supra note 10, at 111 .

14 Petitioners, working under a maintenance of membership contract, remained employed throughout the union trial proceedings and after their expulsion from the union. If, however, the union had obtained petitioners' discharge, the Labor Management Relations Act (Taft-Hartley) would have been applicable and would have afforded a remedy. See note 22 supra.
} 
not survive."25 This freedom would be meaningless if petitioners were required to forego their union membership as the price of speaking out on political issues. ${ }^{26}$ The court emphasized that the community, as well as the individual, has a vested interest in the free exchange of ideas and stands to profit from political debate. After surveying the competing interests, the court concluded that "it could not be more apparent where the balance lies ${ }^{327}$ and ordered petitioners' reinstatement.

In deciding Mitchell, however, the court did not formulate any clear legal principle to replace the rationales traditionally utilized in granting relief to wrongfully expelled union members. Arguably the court could have found such a principle available in the concept of "governmental action." In a related area, the exclusion of minority groups from union membership, the Supreme Court has held that a union under the jurisdiction of the Railway Labor $\mathrm{Act}^{28}$ must represent all members of a bargaining unit without discrimination. ${ }^{28}$ The lower federal courts have not extended this holding to require that a Railway Labor Act union accept all individuals into full membership, regardless of race. ${ }^{30}$ The Supreme Court of Kansas, however, has held that a union's status as collective bargaining agent under the Railway Labor Act transforms it into a government agency: therefore, exclusion of Negroes from full membership and participation in the union amounted to governmental action in violation of the due process clause of the fifth

${ }^{25} 16$ Cal. Rptr. at 818.

${ }^{20}$ The court also pointed out that expulsion has the additional effect of intimidating those members who remain in the union. While admitting that this might be a legitimate objective of the union in some situations, the court added, "the very question to be decided is whether the community ought to tolerate that result in these circumstances." 16 Cal. Rptr. at 818.

"Id. at 819 .

${ }^{28} 44$ Stat. 577 (1926), as amended, 45 U.S.C. $§ \S 151-88$ (1958).

${ }^{20}$ See Railway Employes' v. Hanson, 351 U.S. 225 (1956); Steele v. Louisville \& Nashville R.R., 323 U.S. 192 (1944). See Comment, 42 IowA L. REv. 113 (1956); Comment, 1953 WIs. L. REv. 516.

${ }^{80}$ See Oliphant v. Brotherhood of Locomotive Firemen, 156 F. Supp. 89 (N.D. Ohio), cert. denied, 355 U.S. 893 (1957), aff'd, 262 F.2d 359 (6th Cir. 1958), cert. denied, 359 U.S. 935 (1959). In a suit to compel union admission, the district court denied that Negro fireman had established the necessary nexus between union action and the federal government to constitute a violation of the fifth amendment. "Actions by the Brotherhood can be attributed to the Congress only if the act [Railway Labor Act] ... clothes the Brotherhood with some or all of the attributes of a federal agency. The court is satisfied that this act is not sufficient to change the character of the organization from that of private association to that of governmental agency." 156 F. Supp. at 93. Cf. Ross v. Ebert, 275 Wis. 523, 82 N.W.2d 315 (1957) (denial of membership to Negroes not a violation of fourteenth amendment). 
amendment. ${ }^{31}$ Under the facts of the Mitchell case, a similar argument could be made. ${ }^{32}$ While broader policy considerations may have prevented the California court from resting its decision on this ground, it seems that the court reasonably could have held that the International Association of Machinists, acting under authority of the Labor-Management Relations Act, ${ }^{33}$ violated the United States Constitution in expelling petitioners for exercising their rights of free speech guaranteed by the first amendment. ${ }^{34}$

Commentators have written extensively on the general problem of union discipline and have suggested several remedies for unwarranted union interference with individual expression. Most frequently the remedy proposed is through statutory reform. ${ }^{35}$ Other commentators

"Betts v. Easley, 161 Kan. 459, 169 P.2d 831 (1946).

${ }^{32}$ The Railway Labor Act, unlike the Labor Management Relations Act (TaftHartley Act), permits union shops "notwithstanding any . . . law . . . of any State." 64 Stat. 1238 (1951), 45 U.S.C. $\S 152$ Eleventh (1958). In Railway Employes' v. Hanson, 351 U.S. 225, 231 (1956), Mr. Justice Douglas stated that this permissive language gave a union shop agreement the "imprimatur" of federal law and therefore, prohibited union violation of the first amendment. The International Association of Machinists local lodge in the present case was under the Labor Management Relations Act rather than the Railway Labor Act. Nonetheless, the similarity of the two acts, especially provisions relating to union exclusive collective bargaining rights, seems of greater importance than the differences for present purposes. Under both acts, unions represent all employees of the appropriate unit regardless of whether or not all employees are union members. Compare 61 Stat. 143 (1947), 29 U.S.C. § 159(a) (1958), with 44 Stat. 577 (1926), 45 U.S.C. \$ 152 Fourth (1958).

61 Stat. 136 (1947), 29 U.S.C. $\$ \S 141-97$ (1958).

24 The majority opinion in International Ass'n of Machinists v. Street, 367 U.S. 740 (1961), rested on a statutory interpretation of the Railway Labor Act. Four justices, however, reached the constitutional question. It seems certain, therefore, that the Court eventually will reach the underlying constitutional issue of union interference with freedom of speech. The present case appears even more ripe for constitutional application, since petitioners were punished for political expression and did not merely complain about union political expenditures. See note 23 supra. Wellington, The Constitution, the Labor Union, and "Governmental Action," 70 YALE L.J. 345 (1961), questions the wisdom of applying the concept of governmental action to unions. But cf. Note, 42 MINN. L. REv. 942 (1958). A union member's right of free speech need not be absolute. Therefore in "treason" cases (e.g., where a union member advocates the abolition of unions), courts could formulate a "clear and present danger" test to protect union interests.

${ }^{25}$ A variety of statutory reforms have been suggested: ( 1 ) amendment of the National Labor Relations Act to make expulsion for individual political activities a union unfair labor practice. See American Civil Liberties Union, A Labor Union BiLL of RIGHTs, $\S \S 1, V$, VI (1958); (2) amendment of the act to require that a union submit disputes in this area to an arbitrator with resort by the expelled union member to the National Labor Relations Board in the event that the union refuses. See Williams, supra note I1, at 826 ; (3) passage of a separate statute establishing flexible substantive 
have taken a less drastic view of the reform needed and have suggested that greater judicial emphasis on individual rights of free speech and closer supervision of union internal trial procedure would be sufficient. ${ }^{38}$ Congress apparently is in accord with the last approach, as evidenced by the Labor Management Reporting and Disclosure Act of $1959 .^{37}$ While this act does guarantee union members the right of free speech and assembly in regard to internal union affairs, ${ }^{38}$ it does little more than publicize the existing common law remedies for freedom of expression outside the union..$^{38}$ The enlightened decision and general approach of Mitchell is a vindication of congressional belief that further legislation is not needed to preserve internal union democracy.

and procedural standards of union discipline. See Aaron \& Komaroff, supra note I1.

${ }^{80}$ Wollett \& Lampman, supra note 11 . See also Wellington, supra note 34.

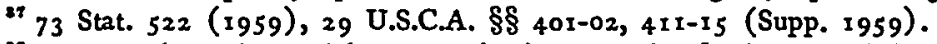

28 "No member of any labor organization may be fined, suspended, expelled, or otherwise disciplined except for nonpayment of dues by such organization or by any officer thereof unless such member has been (A) served with written specific charges; (B) given a reasonable time to prepare his defense; (C) afforded a full and fair hearing." Labor Management Reporting and Disclosure Act $\$$ ror(a)(5), 73 Stat. 522 (1959), 29 U.S.C.A. $\$ 41$ I (a) (5) (Supp. 1959). See Cox, op. cit. supra note 10, at 96-III; Aaron, supra note 6, at 860-66.

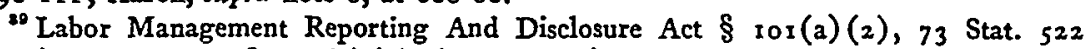
(1959), 29 U.S.C.A. $\S 411$ (a) (2) (Supp. 1959). Sections 102 and 103 provide for civil remedy in both federal and state courts. 


\section{An Index to Modern Legal Problems}

On each of the following topics, LAw AND CONTEMporary ProBleus has publiahed or will publish a symposium dealing with the legal, economic, administrative, and other social-scienco aspects of the subject. The date indicates the year of publication.

Administrative Regulation Agricultural Adjustment in the Bouth Air Cargo

Alcoholic Beverage Control

Alimony

Atomic Power Development

Aviation Transport

Children of Divorced Parents

Close Corporation

Collection of Real Property Tares

Collective Bargaining Under the

Wagner Act

Combating the Loan Shark

Commercial Arbitrationf

Commercial Codef

Consumption Taxes

Cooperatires

Correction of Youtheul Offenders

Crime and Correction

Delivered Pricing

Divorce: A Re-examination of

Basic Concepts

Emergency Price Control Act

Enemy Property

European Regional Communities

Excess Profits Taration

Expert Testimony

Farm Tenancy Legislation

Federal Courts

Federal Emplojers' Liability Actf

Federal Income and Estate Taxation

Federal Powers Over Crime

Financial Protection for the Motor

Accident Victim

Financing Small Business

Food, Drug, and Cosmetic Legislation

Governmental Marketing Barriers

Government Tort Liability

Hemispheric Trade

Home Financing

Housing

Immigration

Instalment Belling

Institutional Investments

International Human Rightst

International Trade Barriers

Interterritorial Freight Rates

Investment of Trust Funds

Labor Disputo Settlement

Labor in Wartime

Land Planning in a Democracy
1961 Legislative Reapportionment

1934 Literary and Artistic Producta and

1950 Copyright Problems

1940 Loan Shark Problem Today

1939 Low-Cost Housing and Slum Clearance 1934

1956 Medical Care 1939

1946 Migratory Divorce 1935

1944 Narcotics 1957

1953 Nationalization of British Industries 1951

1936 New Look in Corporation Law 1958

Obscenity and the Arts

1938 Old Age Security and Welfare Titles

1941

1952

1951

1941

1948

1942

1958

1950

1953

1942

1945

1961

1943

1935

1937

1948

1953

1940

1934

1936

1945

1939

1941

1942

1941

1938

1947

1956

1935

1952

1949

1946

1947

1938

1947

1942

1955

of the Social Security Act

Patent System f

Population Control

Presidential Office

Preventive Law of Conflicts

Price Control in a Cold War

Price Discrimination and Prico Cutting

Private Insurance

Protection for the Consumer of

Food and Drugs

Public Anthorities

Radio and Televisiont

Railroad Reorganization

Regulation of Insurance

Regulation of Natural Gas

Religion and the State

River Basin Development

1955

School Pupils and the Law

Secured Commorcial Financing

Securities Actf

Sentencing

Sex Offenses

Sherman Antitrust Act and Its

Enforcement

Small Business

State Tradingt

Trade-Marks in Transition

"Transportationf Controversy

1936

Unemployment Compensation

Urban Housing and Planning

Urban Renewalt

Wage Earners' Life Insurance

Wage and Hour Law

War Claims

War Contract Renegotiation

War Contract Termination 1

Water Resources
1947, 1948

1960

1950

1956

1954

1937

1950

1833

1961

1957, 1958

1940

1950

1954

1949

1957

1955

1948

1937

1958

1960

1940

1959

1959

1949

1959,1960

1938

1936

1956

1960, 1961

1935

1951

1943

1944

1957

Subscriptions: $\$ 7.50$ per jear ( $\$ 8.00$ foreign; $\$ 7.85$ Canada; $\$ 7.85$ Pan America).

Single Copies: $\$ 2.50$ each ( $\$ 2.65$ foreign, $\$ 2.60$ Canada, $\$ 2.60$ Pan America). Copies of all back issues are available.

Bulk Orders: On orders for ten or more copies of a single issue a discount of 20 per ceut is applicable, f.o.b. Durham, N. C.

Complete sets: Arrangements can be made to supply complete sets, unbound, at a discount of 20 per cent from the combined price for the individual issues, f.o.b. Durham, N. O.

$t$ Pablished in two parts, priced separately.

LAW AND CONTEMPORARY PROBLEMS 